\title{
Antibacterial and Antibiotic-Modifying Activity of Methanol Extracts from Six Cameroonian Food Plants against Multidrug-Resistant Enteric Bacteria
}

\author{
Joachim K. Dzotam and Victor Kuete \\ Department of Biochemistry, Faculty of Science, University of Dschang, Dschang, Cameroon \\ Correspondence should be addressed to Victor Kuete; kuetevictor@yahoo.fr
}

Received 20 March 2017; Revised 30 May 2017; Accepted 18 July 2017; Published 20 August 2017

Academic Editor: Gail B. Mahady

Copyright (C) 2017 Joachim K. Dzotam and Victor Kuete. This is an open access article distributed under the Creative Commons Attribution License, which permits unrestricted use, distribution, and reproduction in any medium, provided the original work is properly cited.

\begin{abstract}
The present work was designed to investigate the antibacterial activities of methanol extracts from six Cameroonian edible plants and their synergistic effects with some commonly used antibiotics against multidrug-resistant (MDR) Gram-negative bacteria expressing active efflux pumps. The extracts were subjected to qualitative phytochemical screening and the microdilution broth method was used for antibacterial assays. The results of phytochemical tests indicate that all tested crude extracts contained polyphenols, flavonoids, triterpenes, and steroids. Extracts displayed selective antibacterial activities with the minimal inhibitory concentration (MIC) values ranging from 32 to $1024 \mu \mathrm{g} / \mathrm{mL}$. The lowest MIC value $(32 \mu \mathrm{g} / \mathrm{mL})$ was recorded with Coula edulis extract against E. coli AG102 and K. pneumoniae K2 and with Mangifera indica bark extract against P. aeruginosa PA01 and Citrus sinensis extract against $E$. coli W3110 which also displayed the best MBC $(256 \mu \mathrm{g} / \mathrm{mL})$ value against E. coli ATCC 8739 . In combination with antibiotics, extracts from $M$. indica leaves showed synergistic effects with $75 \%$ (6/8) of the tested antibiotics against more than $80 \%$ of the tested bacteria. The findings of the present work indicate that the tested plants may be used alone or in combination in the treatment of bacterial infections including the multidrug-resistant bacteria.
\end{abstract}

\section{Introduction}

The discovery of antibiotics has inevitably fostered the development and emergence of resistances in bacteria, regardless of the mechanism of action of the antibiotic involved. For decades, and in order to reduce the development and epidemic spread of resistance, physicians and scientists have called for appropriate use of antibiotics [1]. Prudent use of antibiotics in humans demands that physicians establish that a bacterial infection is responsible for the patient's symptoms before an antibiotic prescription is made. By contrast, in agriculture, antibiotics are used in the absence of acute infection [2]. Bacteria faced with this fierce struggle against them have developed several mechanisms of resistance against antimicrobial agents whose main ones include enzymatic inactivation [3], modification of the drug target(s), and reduction of intracellular drug concentration by changes in membrane permeability or by the overexpression of efflux pumps [4]. With respect to efflux pumps, they provide a selfdefense mechanism by which antibiotics are actively removed from the cell. For antibacterials, this results in sublethal drug concentrations at the active site that in turn may predispose the organism to the development of high-level target-based resistance [5]. In this way, efflux pumps inevitably become targets for the research and/or development of new, less toxic, and effective molecules capable, alone or in combination with the usual antibiotics, of effectively fighting infections involving multidrug-resistant pathogens. Medicinal plants in general and food plants in particular have been used for centuries to cure ailments of man. Today, there is a real revival of interest in these almost-exploited sources [6] of molecules whose pharmacological efficacy is no longer to be demonstrated [7]. The present work was designed to investigate the in vitro ability of methanol extracts from six Cameroonian edible plants (Psidium guajava Linn., Persea americana Mill., Camellia sinensis Linn., Mangifera indica 
Linn., Coula edulis Baill., and Citrus sinensis Linn.), to potentiate the activity of some commonly used antibiotics vis-à-vis Gram-negative multidrug-resistant bacteria.

\section{Material and Methods}

2.1. Plant Material and Extraction. The plant materials used in this work were collected in the period of March to April 2015 in two regions of Cameroon and included leaves and bark of $M$. indica; fruits, leaves, and bark of P. guajava; leaves and bark of $P$. americana collected at Koung-Khi division (West Region); leaves of $C$. sinensis and the fruits of $C$. sinensis collected at Menoua division (West Region); and nuts of C. edulis collected at Mungo division (Littoral Region). The plants were identified at the National Herbarium (Yaounde, Cameroon) where voucher specimens were deposited under the reference numbers (Table 1). Each plant sample was cleaned and air-dried and the powder $(300 \mathrm{~g})$ was extracted with methanol $(\mathrm{MeOH}, 1 \mathrm{~L})$ for $48 \mathrm{~h}$ at room temperature. The extract was then concentrated under reduced pressure to give residues which constituted the crude extract. All extracts were then kept at $4^{\circ} \mathrm{C}$ until further use.

2.2. Preliminary Phytochemical Investigations. The major phytochemical classes such as alkaloids (Dragendorff's and Mayer's tests), triterpenes (Liebermann-Burchard's test), flavonoids (aluminum chloride test), anthraquinones (Borntrager's test), polyphenols (ferric chloride test), sterols (Salkowski's test), coumarins (lactone test), saponins (foam test), and tannins (gelatin test) (Table 2) were investigated according to the commonly described phytochemical methods $[43,44]$.

2.3. Bacteria Strains and Culture Media. The studied bacteria strains included reference (from American Type Culture Collection) and clinical (Laboratory collection) strains of Escherichia coli, Enterobacter aerogenes, Klebsiella pneumoniae, Providencia stuartii, and Pseudomonas aeruginosa. Their bacterial features were previously reported $[45,46]$. They were maintained on agar slant at $4^{\circ} \mathrm{C}$ and subcultured on a fresh appropriate agar plates $24 \mathrm{~h}$ prior to any antimicrobial test. Mueller-Hinton Agar (MHA) was used for the activation of bacteria, while Mueller-Hinton Broth (MHB) was used for the MIC determinations.

2.4. Chemicals for Antimicrobial Assays. The reference antibiotics used in the present work included tetracycline (TET), cefepime (CEP), ciprofloxacin (CIP), streptomycin (STP), chloramphenicol (CHL), ampicillin (AMP), erythromycin (ERY), and kanamycin (KAN), all provided by Sigma-Aldrich, St Quentin Fallavier, France. $p$-Iodonitrotetrazolium (INT) chloride and phenylalanine-arginine- 3 naphthylamide (PAßN) were used as microbial growth indicator and efflux pumps inhibitor (EPI), respectively [47].

2.5. Bacterial Susceptibility Determination. Rapid INT colorimetric assay [47] with some modifications [48] was used to determine the minimal inhibitory concentrations (MIC) of the plant extracts and those of reference antibiotics (RA) against the studied bacteria. The test samples and RA were first of all dissolved in DMSO/Mueller-Hinton Broth (MHB). The final concentration of DMSO was lower than $2.5 \%$ and did not affect the microbial growth [49]. The solution obtained was then added to Mueller-Hinton Broth and serially diluted twofold (in a 96-well microplate). One hundred microliters $(100 \mu \mathrm{L})$ of inoculum $1.5 \times 10^{6} \mathrm{CFU} / \mathrm{mL}$ prepared in appropriate broth was then added $[48,50]$. The plates were covered with a sterile plate sealer, then agitated to mix the contents of the wells using a plate shaker, and incubated at $37^{\circ} \mathrm{C}$ for $18 \mathrm{~h}$. The assay was repeated thrice. Wells containing adequate broth, $100 \mu \mathrm{L}$ of inoculum, and DMSO to a final concentration of $2.5 \%$ served as negative control. The MIC of samples was detected after $18 \mathrm{~h}$ incubation at $37^{\circ} \mathrm{C}$, following addition $(40 \mu \mathrm{L})$ of $0.2 \mathrm{mg} / \mathrm{mL}$ of INT and incubation at $37^{\circ} \mathrm{C}$ for $30 \mathrm{~min}$. Viable bacteria reduced the yellow dye to pink. MIC was defined as the sample concentration that prevented the color change of the medium and exhibited complete inhibition of microbial growth [47]. The MBC was determined by adding $50 \mu \mathrm{L}$ aliquots of the preparations, which did not show any growth after incubation during MIC assays, to $150 \mu \mathrm{L}$ of adequate broth. These preparations were incubated at $37^{\circ} \mathrm{C}$ for $48 \mathrm{~h}$. The $\mathrm{MBC}$ was regarded as the lowest concentration of extract, which did not produce a color change after addition of INT as mentioned above [50].

The role of efflux pumps in the susceptibility of Gramnegative bacteria to $M$. indica, $C$. edulis, $C$. sinensis, leaves from $P$. guajava, $P$. americana, and $C$. sinensis, and crude extracts was evaluated by testing them in the presence of an efflux pump inhibitor (EPI), the PA $\beta \mathrm{N}$ (at $30 \mu \mathrm{g} / \mathrm{mL}$ ) against fifteen selected MDR phenotypes (E. coli AG100A, AG102, and AG100ATet, E. aerogenes EA289, EA27, EA298, and CM64, K. pneumoniae KP55 and KP63, E. cloacae BM47, BM67, and ECCI69, P. aeruginosa PA124, and P. stuartii NAE16 and PS2636).

To evaluate the potentiating effect of tested extracts, a preliminary combination at their subinhibitory concentrations (MIC/2, MIC/4, MIC/8, and MIC/16) with antibiotics was assessed against $P$. aeruginosa PA124 strain (see Table S1 in Supplementary Material available online at https://doi .org/10.1155/2017/1583510). The appropriate subinhibitory concentrations were then selected on the basis of their ability to improve the activity of the maximum antibiotic [51, 52]. These subinhibitory concentrations for selected extracts were further tested in combination with antibiotics against more MDR bacteria. The fractional inhibitory concentration (FIC) of each combination was then calculated as the ratio of MIC of antibiotic in combination versus MIC of antibiotic alone $\left(\mathrm{MIC}_{\text {Antibiotic in combination }} / \mathrm{MIC}_{\text {Antibiotic alone }}\right)$ and the interpretation made was as follows: synergistic $(\leq 0.5)$, indifferent $(1$ to 4$)$, or antagonistic $(>4)[53,54]$. All assays were performed in triplicate.

\section{Results}

3.1. Phytochemical Composition of Plant's Extracts. The results of the phytochemical screening (Table 2) showed that all the tested plant's extracts contain polyphenols, flavonoids, 


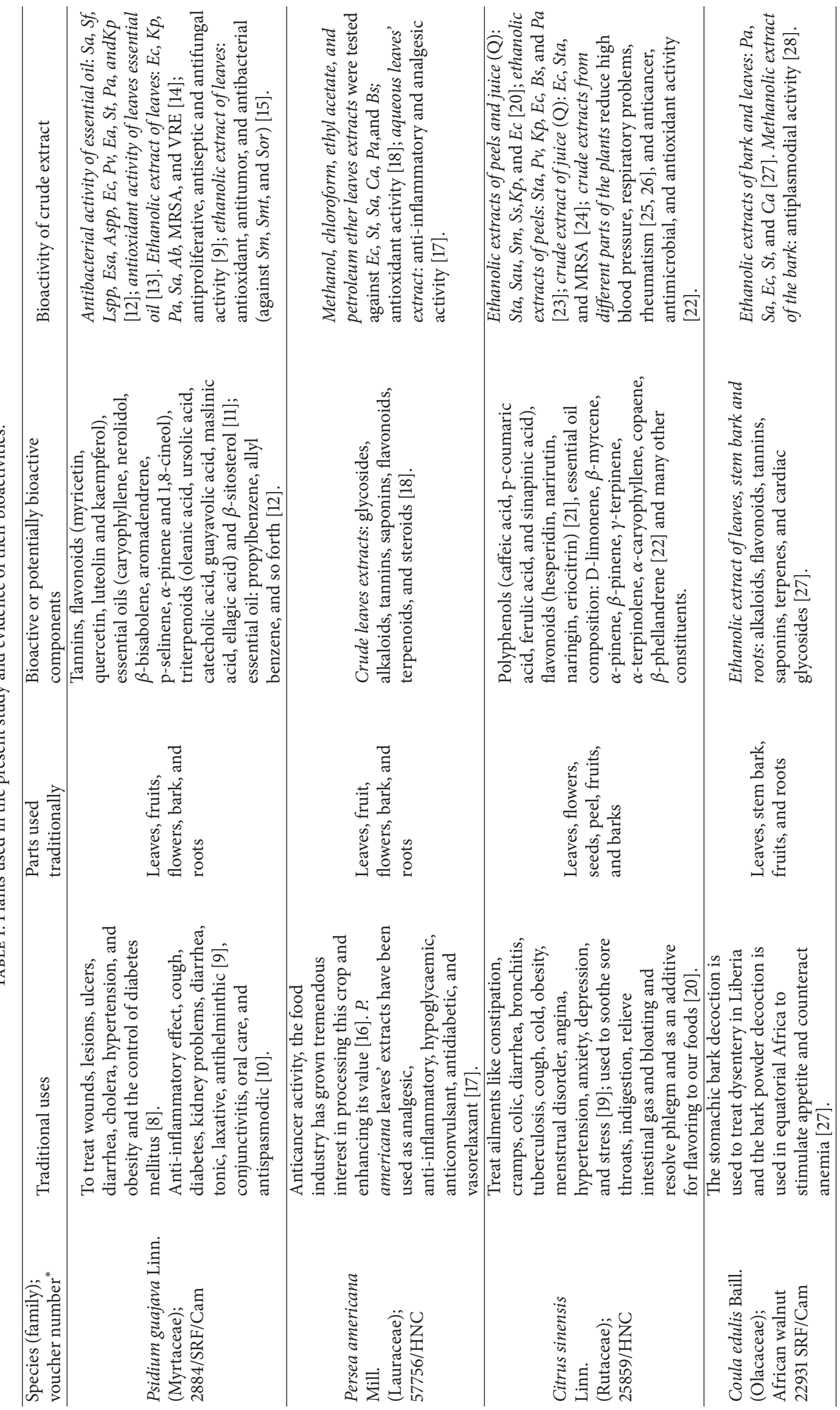




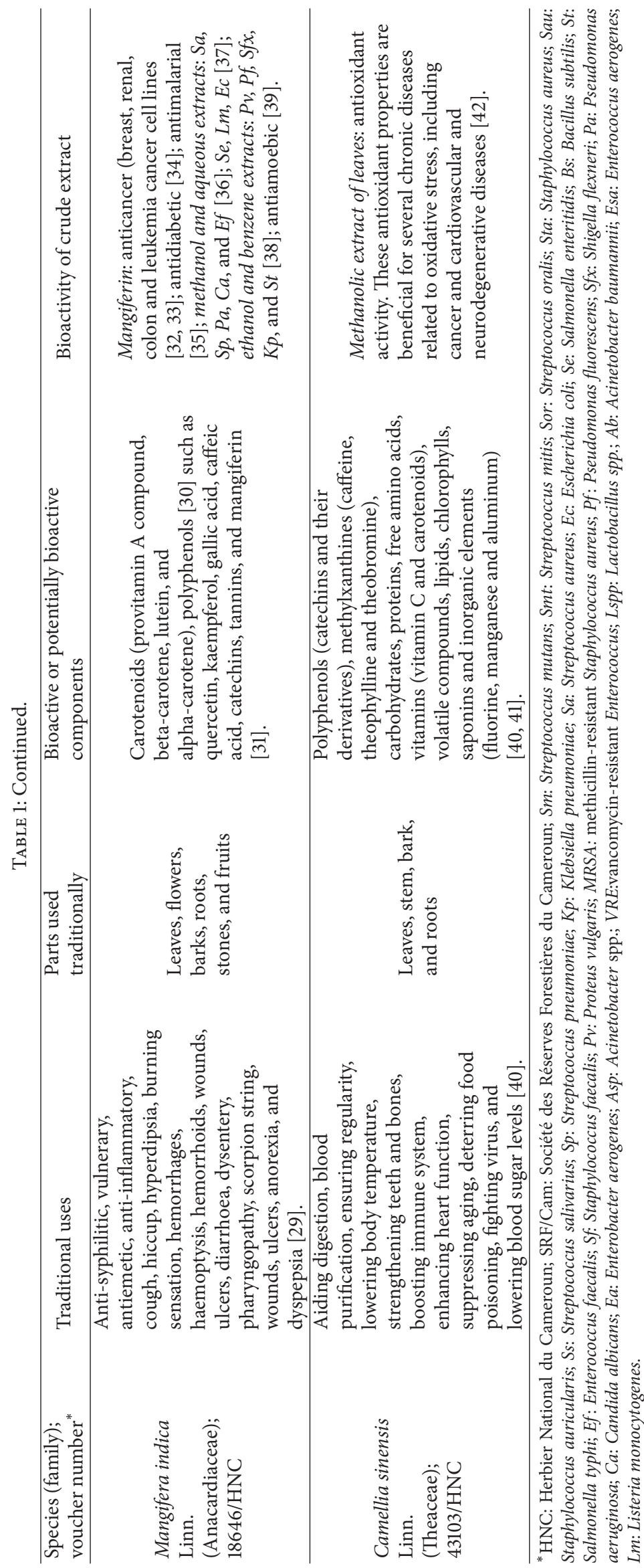


TABLE 2: Extraction yields, aspects, and phytochemical composition of the plant extracts.

\begin{tabular}{lccccccccccc}
\hline Extracts & \multicolumn{3}{c}{ Psidium guajava } & \multicolumn{2}{c}{ Persea } & americana & Citrus sinensis & Coula edulis & Mangifera indica & Camellia sinensis \\
\hline Parts used & Leaves & Bark & Fruits & Leaves & Bark & Peel & Fruits & Leaves & Bark & Leaves \\
Yield* (\%) & 5.47 & 4.17 & 6.12 & 5.15 & 4.47 & 6.56 & 7.25 & 5.36 & 4.26 & 5.8 \\
Alkaloids & + & + & - & + & + & + & + & + & + & + & + \\
Polyphenols & + & + & + & + & + & + & + & + & + & + \\
Flavonoids & + & + & + & + & + & + & + & + & + & + \\
Anthraquinones & - & - & - & + & + & + & + & + & + \\
Coumarins & + & + & + & + & + & + & + & + & + \\
Tannins & + & + & - & + & + & + & + & + & + \\
Triterpenes & + & + & + & + & + & + & + & + & + \\
Sterols & + & + & + & + & + & + & + & + & + & + \\
Saponins & + & + & - & + & + & + & + & + & + \\
\hline
\end{tabular}

-: absent; +: present; ${ }^{*}$ yield calculated as the ratio of the mass of the obtained methanol extract/mass of the plant powder.

triterpenes, and sterols. The other classes of secondary metabolites were selectively distributed. Also, the extract from the leaves and bark of P. americana as well as those of $M$. indica and the extract from $C$. edulis nuts contain all the classes of screened secondary metabolites.

3.2. Antibacterial Activity of the Extracts. The antibacterial activities of plants' extracts alone and in some cases, in the presence of the PA $\beta \mathrm{N}$ on a panel of 29 Gram-negative bacteria, was investigated (Table 3 ). It appears that P. guajava leaves extract inhibited the growth of all (100\%) the tested bacteria, and the recorded MICs ranged from 256 to $1024 \mu \mathrm{g} / \mathrm{ml}$. Other samples showed very selective activity; their inhibitory activities were recorded on 26/29 (89.65\%; P. guajava bark and P. americana leaves and bark), 25/29 (82.75\%; C. sinensis), 23/29 (79.31\%; C. edulis), 22/29 (75.86\%; C. sinensis), 21/29 (72.41\%; M. indica leaves and bark), and $11 / 29$ (37.93\%; P. guajava fruits). The lowest MIC value of $32 \mu \mathrm{g} / \mathrm{mL}$ was recorded with the crude extract of $C$. edulis against E. coli AG102 and $K$. pneumoniae K2, as well as with the extract from bark of $M$. indica against $P$. aeruginosa PA01 and the extract of $C$. sinensis against E. coli W3110. Extract from $C$. sinensis displayed the best MBC $(256 \mu \mathrm{g} / \mathrm{mL})$ value against E. coli ATCC8739.

3.3. Role of Efflux Pumps in the Susceptibility of Gram-Negative Bacteria to the Tested Plant Extracts. Fifteen of the studied MDR bacteria were also tested for their susceptibility to plant extracts in the presence of the $\mathrm{PA} \beta \mathrm{N}$ at $30 \mu \mathrm{g} / \mathrm{ml}$. The results showed that when combined with extracts, $\mathrm{PA} \beta \mathrm{N}$ improves the activity (decrease of MIC values) of $C$. sinensis on 11/15 (73.33\%) tested MDR strains. EPI also improved the activity of other extracts against the selected bacteria (Table 3 ).

3.4. Effects of the Association of Extracts with Antibiotics. A preliminary study performed against $P$. aeruginosa PA124 allowed us to select six out of ten extracts at the appropriate subinhibitory concentrations of $\mathrm{MIC} / 2$ and $\mathrm{MIC} / 4$ for further studies. All the six extracts were combined separately to eight antibiotics (CIP, STP, CHL, ERY, KAN, TET, CEF, and
AMP) to evaluate their possible synergetic effects. The results summarized in Tables $4-9$ showed that the synergic effects were noted with all the tested extracts with most of the tested antibiotics except $\beta$-lactams (CEF and AMP). At MIC/2, the extract from $M$. indica leaves showed synergistic effects with 7 of the 8 antibiotics (CIP, STP, CHL, ERY, KAN, TET, and AMP) (87.5\%) against at least 70\% MDR bacteria for each antibiotic. At that same MIC, $C$. sinensis extract improved the activity of all (8/8) tested antibiotics against at least $50 \%$ of the tested MDR bacteria. Synergies with FIC ranging from 0.5 to $<0.007$ were noted with the associations of each of the seven extracts with antibiotics. These low FIC values obtained in the majority of cases (FIC $<0.007$ for associations of $M$. indica $+\beta$-lactams vis-à-vis almost all the bacterial strains and also with many other extracts with streptomycin against many bacterial strains) indicate that extracts have potentiated the activity of antibiotics vis-à-vis the studied bacteria.

\section{Discussion}

Chemical Composition of the Tested Plant Extracts. Phytochemical screening revealed the presence of several classes of secondary metabolites such as alkaloids, polyphenols, flavonoids, anthraquinones, coumarins, saponins, tannins, triterpenes, and steroids. Several in vitro experiments proved that molecules belonging to these classes were found active on pathogenic microorganisms [55].

Antibacterial Activity of the Tested Extracts. After several decades of antibiotic use, pathogenic bacteria of human and animal origin have reached alarming levels of resistance. The reduced efficacy and increasing toxicity of synthetic drugs further aggravate this problem. Scientists are thus directed to seek more active natural or organic molecules [14]. It is imperative in developing countries that effective and less expensive antibacterials should be developed to accommodate all patients, regardless of financial status, in order to eliminate some human factors that can cause MDR. Medicinal plants have known to possess antimicrobial properties against MDR phenotypes [48-50, 56-59] and differences observed between 


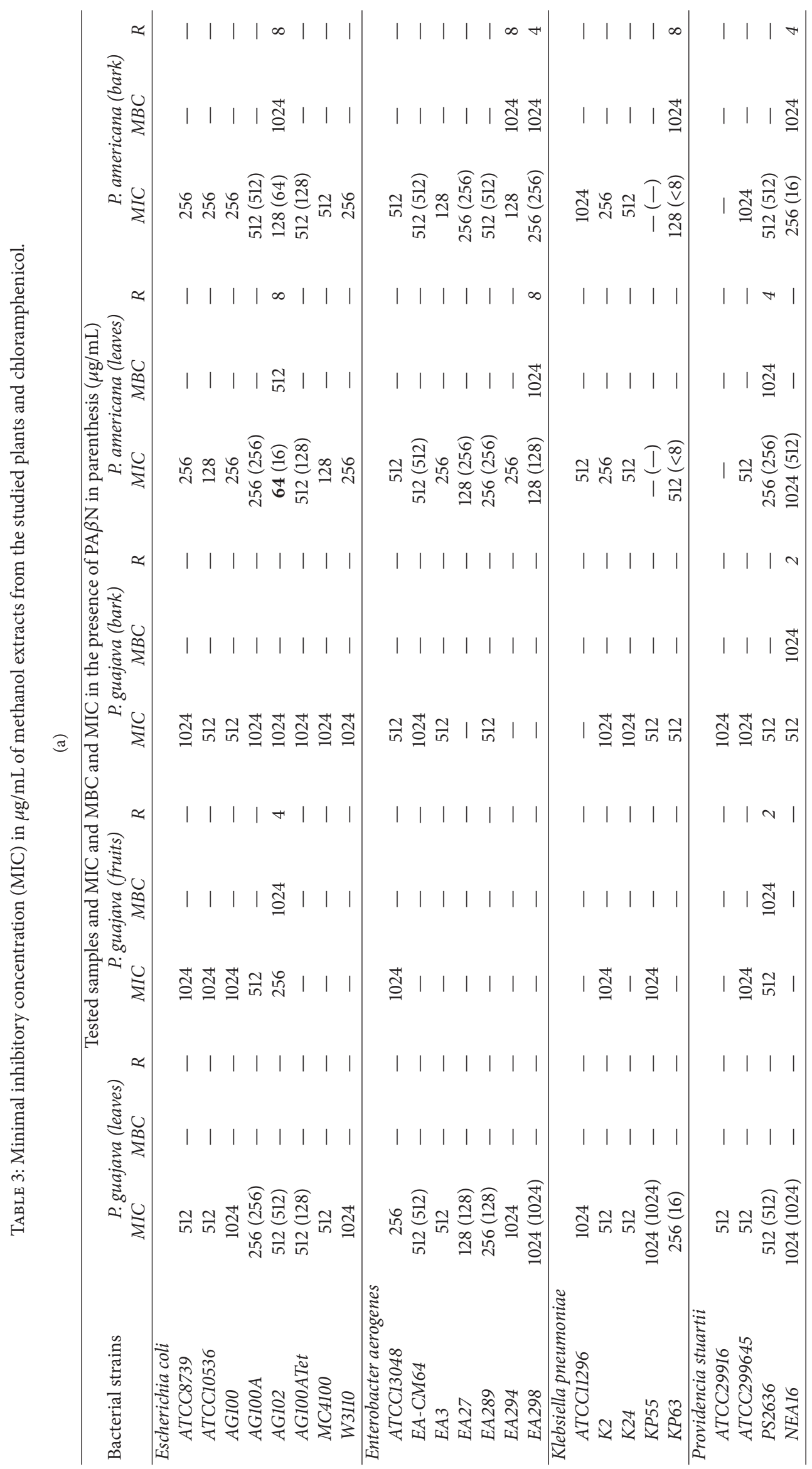




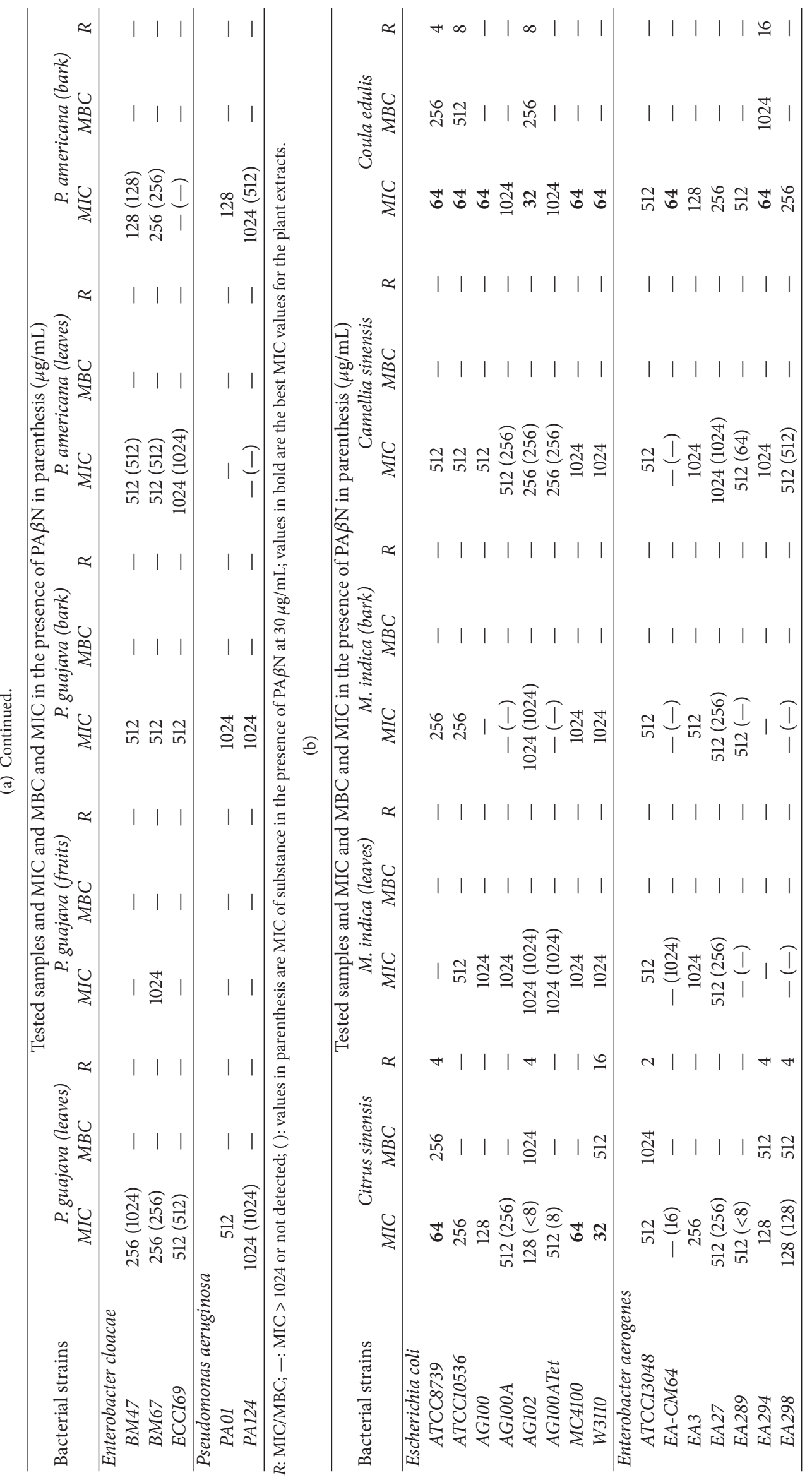




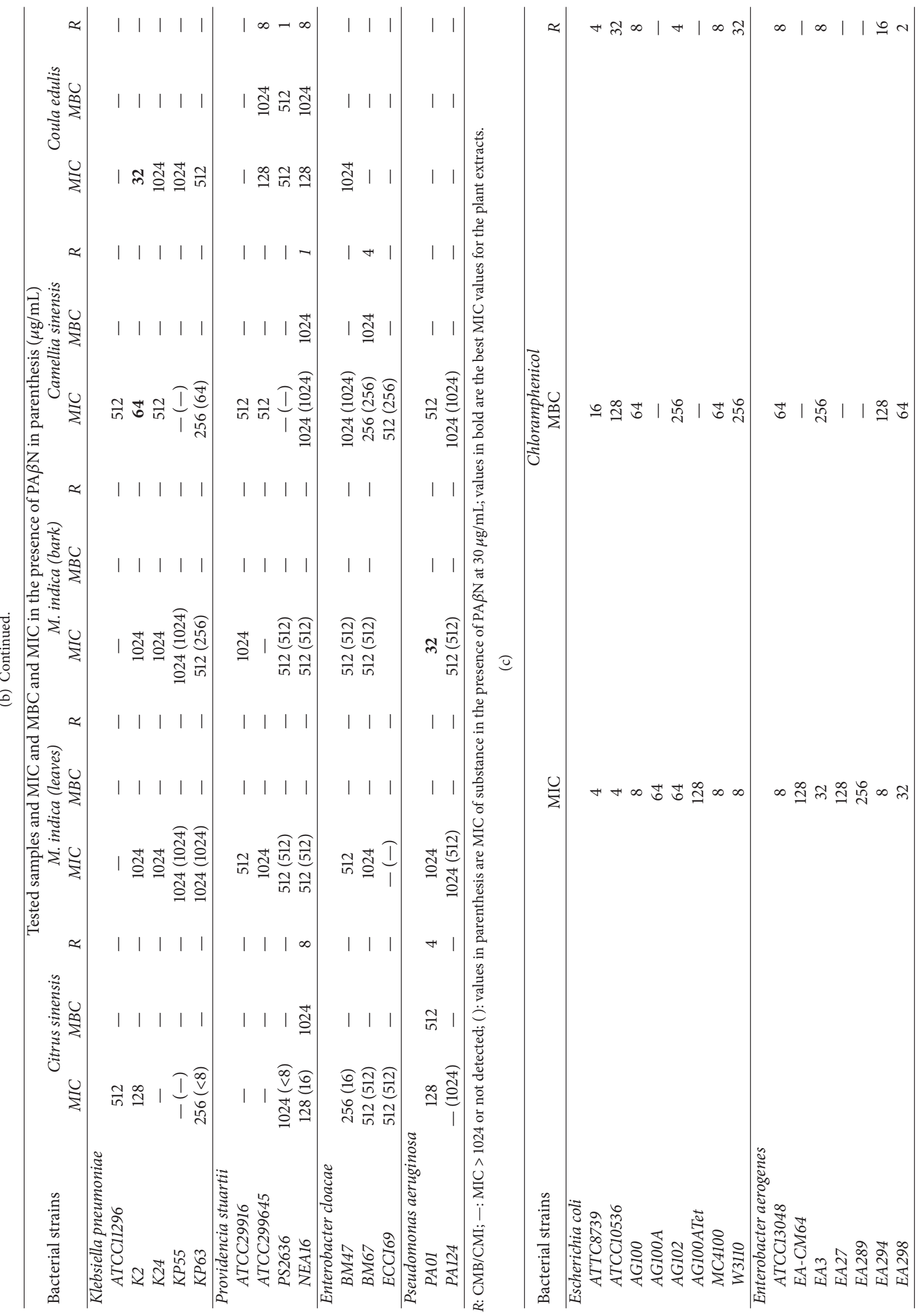




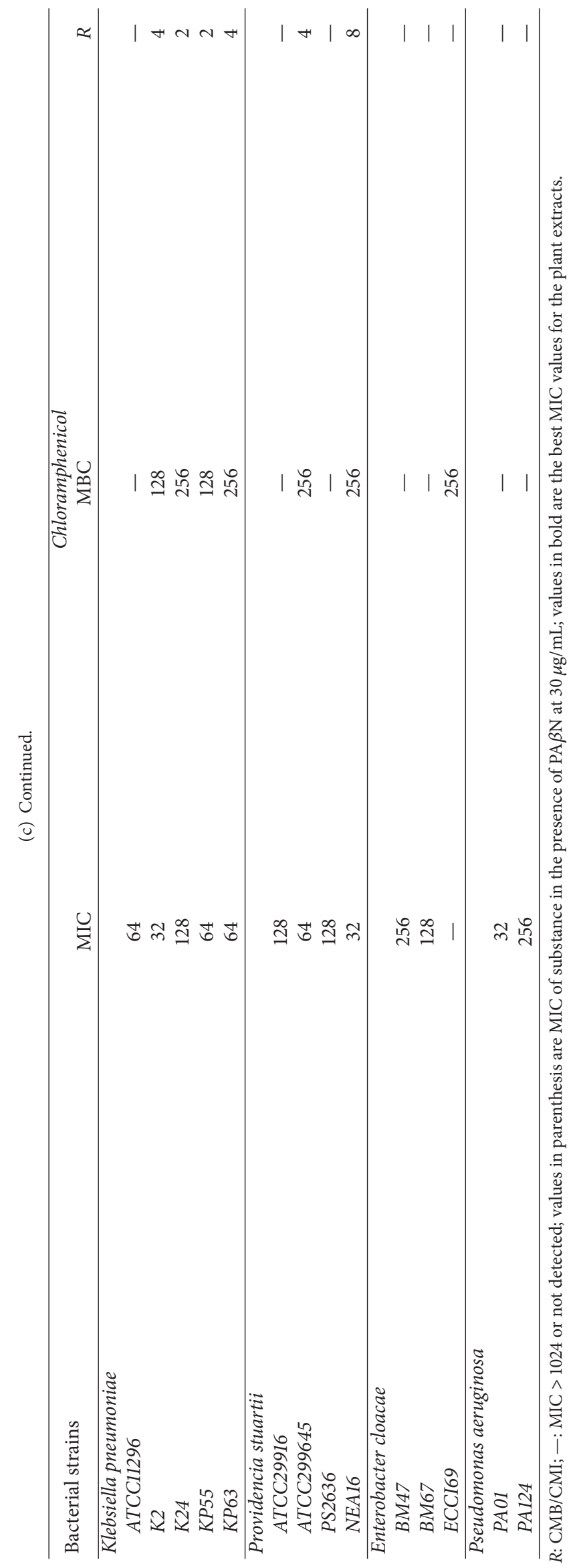




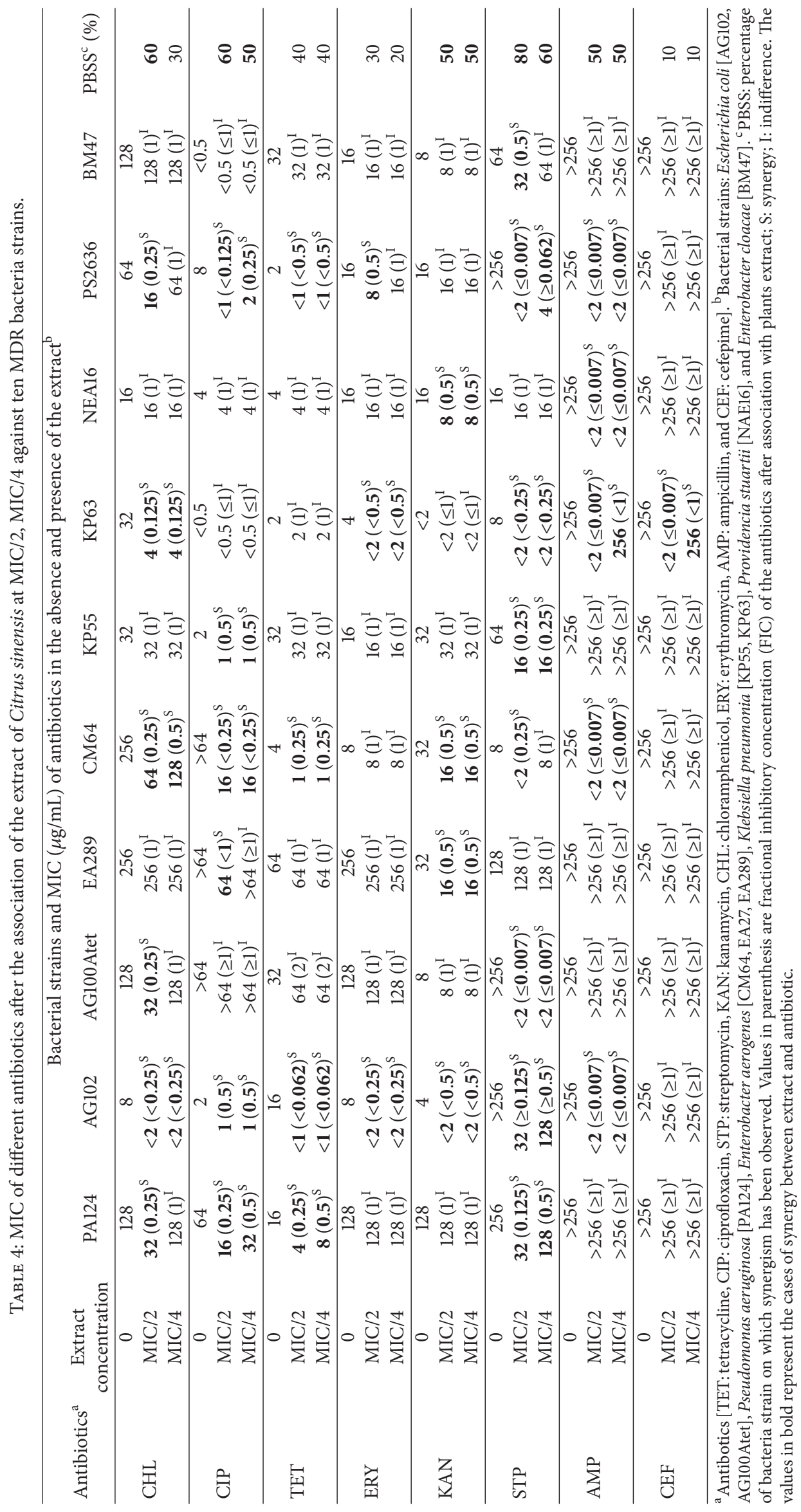




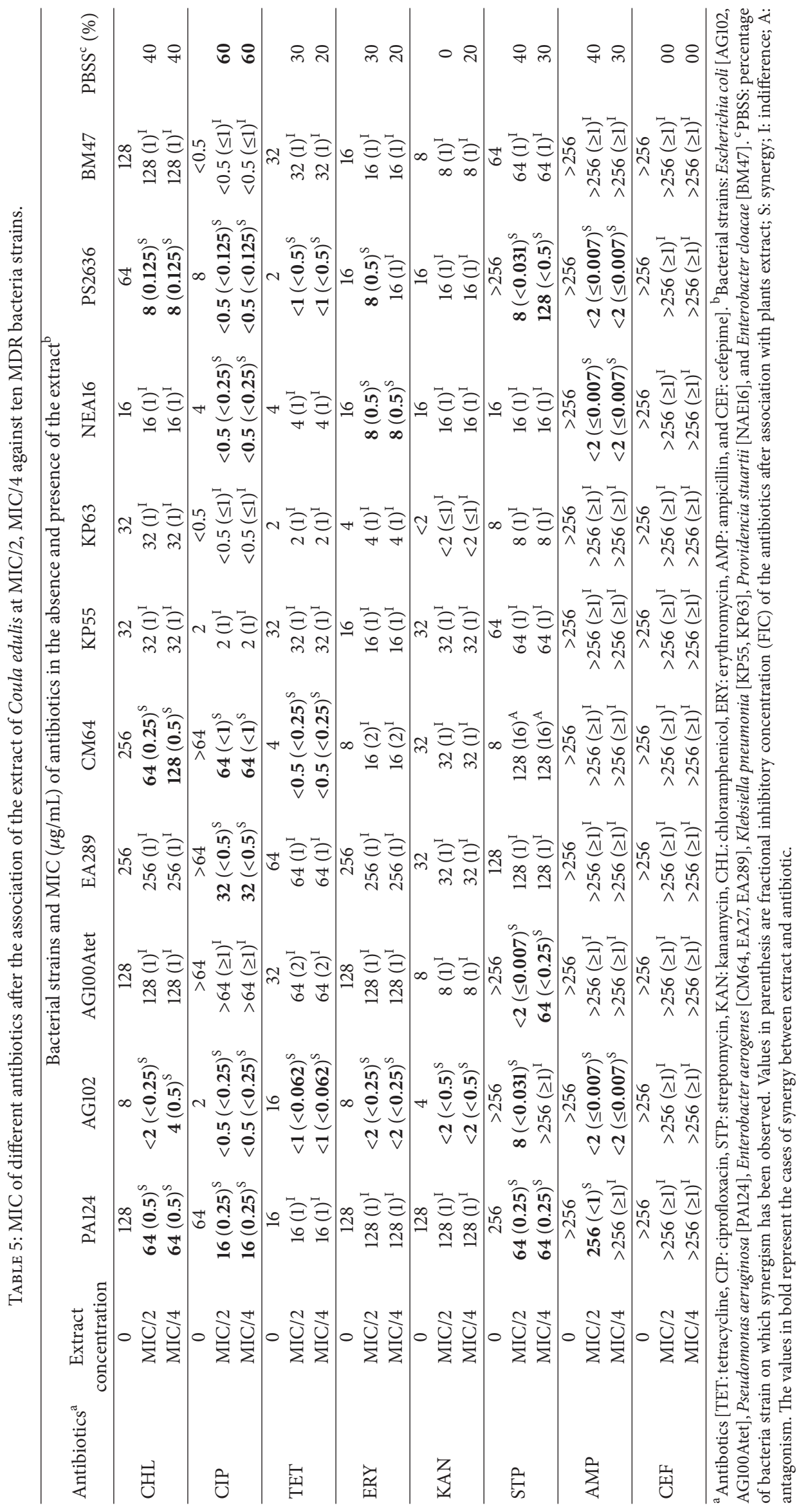




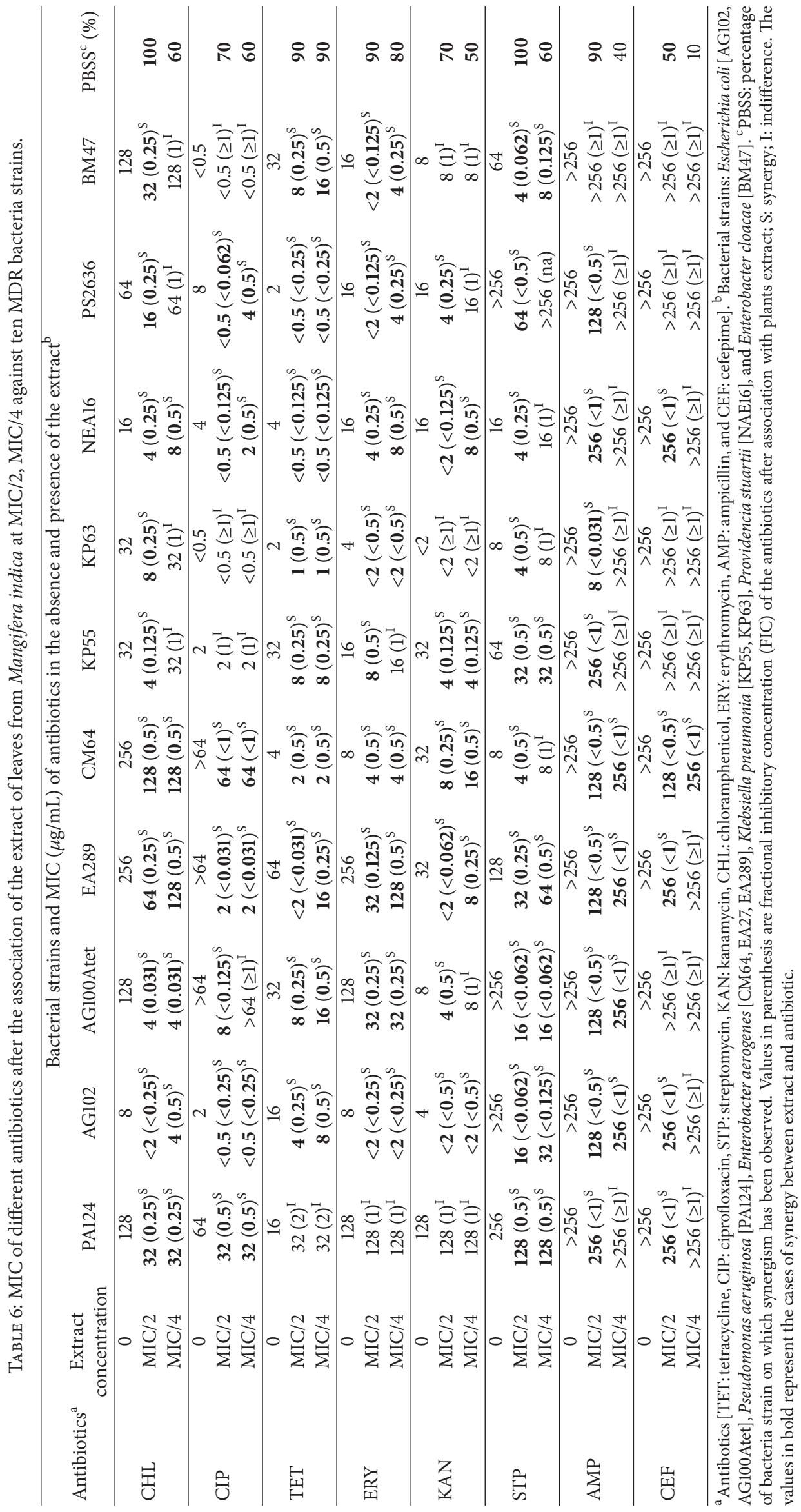




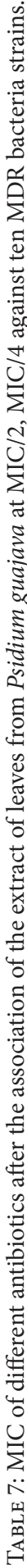

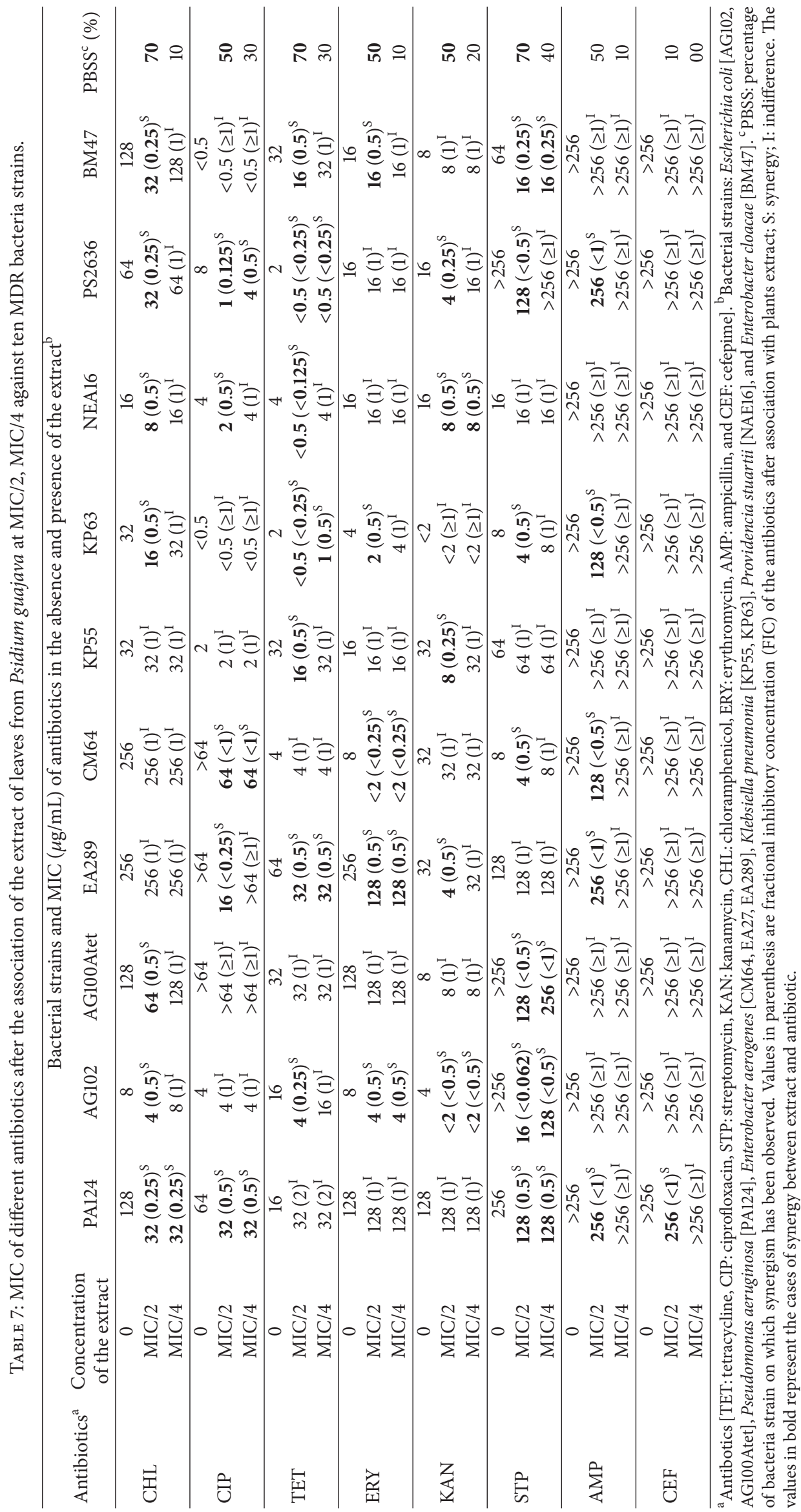




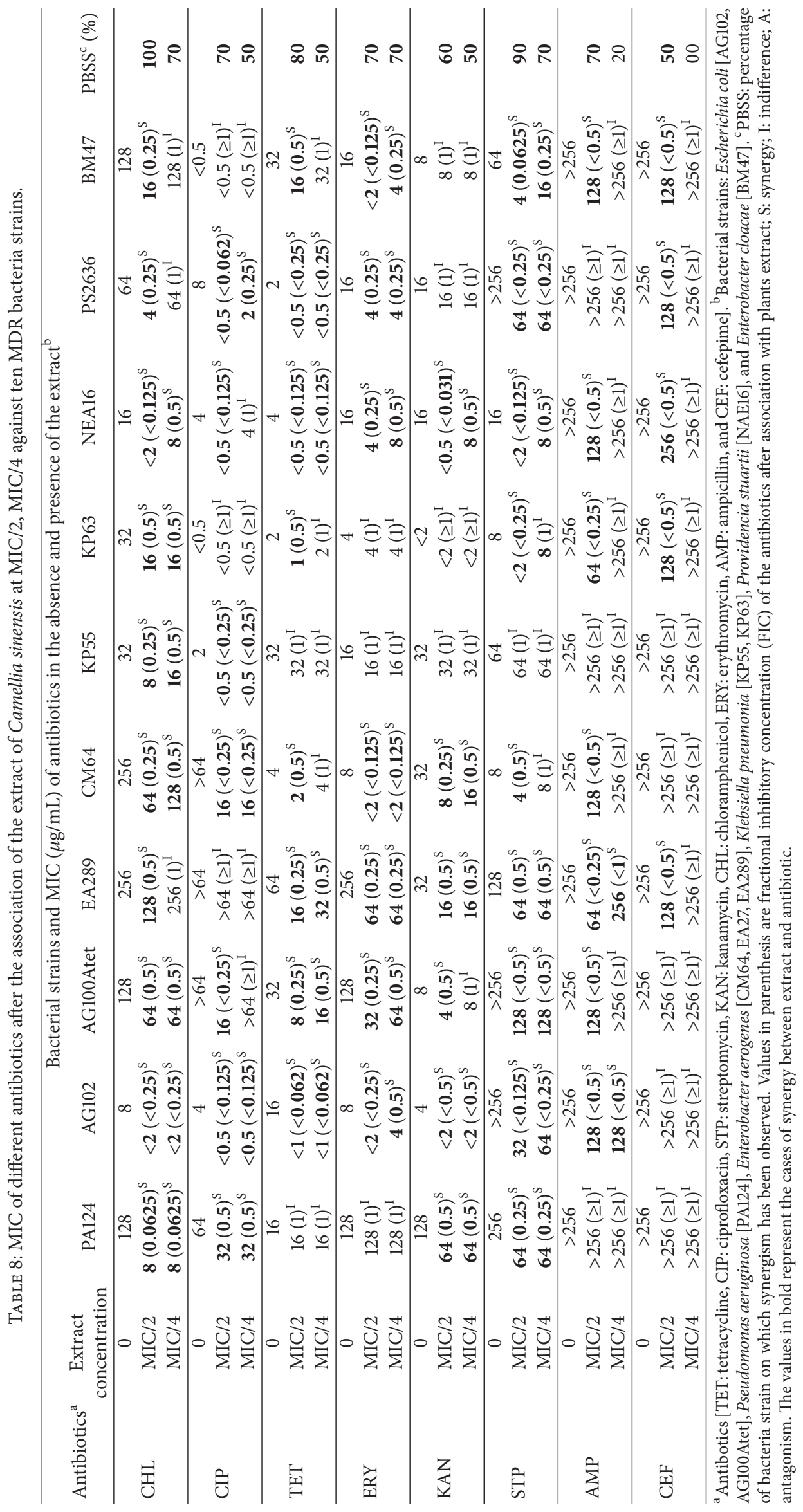


है

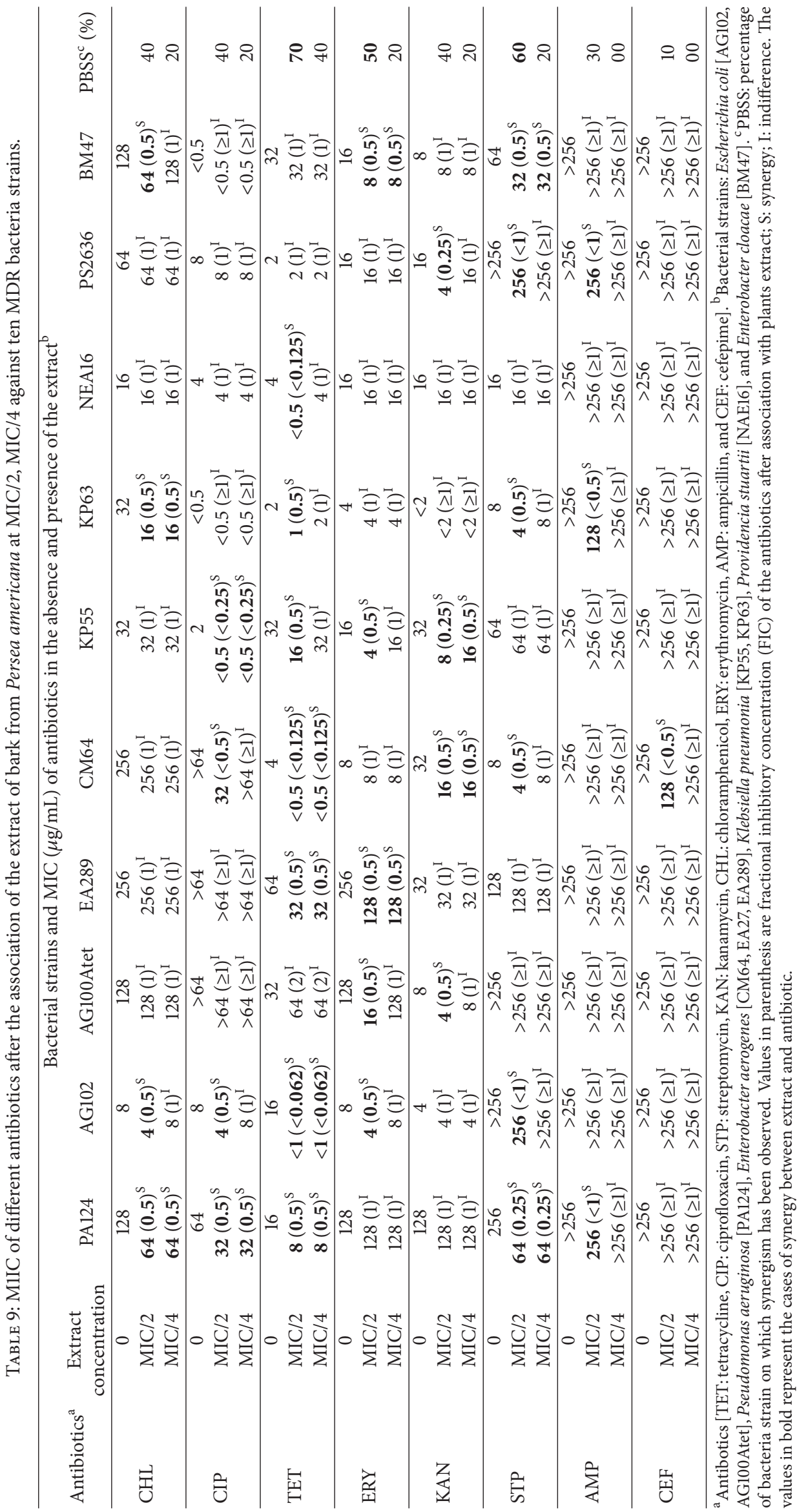


antibacterial activities of the extracts in the present study could be due to the differences in the composition as well as the mechanism of action of their bioactive compounds $[55,60]$. Different solvents extracts of leaves from $P$. guajava have been separately documented to be inhibitory against both Gram-positive and Gram-negative bacteria [14, 15, 61]. In the present study, methanol extract from $P$. guajava leaf demonstrated significant inhibitory activities against both sensitive and MDR bacteria, confirming the previous reports on its antimicrobial activity. According to Kuete and Efferth [62], the antibacterial activity of a plant extract is considered significant when MIC values are below $100 \mu \mathrm{g} / \mathrm{mL}$, moderate when $100 \leq \mathrm{MICs} \leq 625 \mu \mathrm{g} / \mathrm{mL}$, and weak when MICs $>625 \mu \mathrm{g} / \mathrm{mL}$. Consequently, the methanol P. guajava leaf extract tested herein had moderate activity. Besides, the activity (MIC of 32 and $64 \mu \mathrm{g} / \mathrm{mL}$ ) observed with $C$. edulis nuts and $M$. indica bark as well as $C$. sinensis leaves extracts against E. coli AG102, P. aeruginosa PA01, and $K$. pneumoniae $\mathrm{K} 2$, respectively, can be considered important. The antibacterial activities of mango ( $M$. indica) extracts against some microorganisms (Gram-positive and Gramnegative bacteria and Candida albicans yeast) have already been demonstrated $[38,63]$ and it is thought that the antibacterial activity of mango extract is due to the presence of gallotannin and mangiferin [64]. Different extracts of $C$. sinensis having antimicrobial activity were reported against Gram-positive and Gram-negative bacteria and fungi $[65,66]$ and it is thought that their antibacterial activities are due to the presence of catechin. In fact, catechin particularly affects the membrane fluidity in both hydrophilic and hydrophobic regions of lipid bilayers of the microorganism [67] or inhibits the action of DNA polymerases [68]. The present study provides additional data on the ability of this plant to fight MDR bacteria.

The leaves of $P$. americana are widely used for ethnomedicinal purposes worldwide. In order to confirm its multiple medicinal properties, a study conducted by Nathaniel et al. [18] showed that the methanolic extract from leaves of $P$. americana had good antimicrobial activity against enteric microorganisms (Gram-negative and Gram-positive bacteria and also yeasts). This is in accordance with the present study as we also found that methanol extracts of both leaves and bark of the plant exhibited similar activities against several MDR bacteria, with leaves' extract having good inhibitor effects $(64 \mu \mathrm{g} / \mathrm{mL})$ against the E. coli AG102 strain. Considering the fact that some of the tested plants are used as food with limited toxicity, the overall activity recorded with several extracts, most notably those of $C$. sinensis, C. sinensis, and C. edulis or the fruits from P. guajava, could be considered important. However, a threshold for significant antibacterial effects has been proposed for MIC values ranging within $100-512 \mu \mathrm{g} / \mathrm{mL}$ when samples tested are edible parts of plants [69].

Role of Efflux Pumps in the Susceptibility of Gram-Negative Bacteria to the Tested Extracts. The studied bacterial strains used in this work mostly resist by efflux mechanism, which consists in expelling all toxic compounds (including antibiotics) out of the cytoplasm, thus preventing them from reaching their intracellular targets [70]. These efflux pumps can however be blocked competitively or not, in order to restore not only the intracellular concentration but also the activity of antibacterials acting on intracellular targets [71]. In the presence of PA $\beta \mathrm{N}$ (EPI), the antibacterial activity of $C$. sinensis extract was improved on 11/15 (73.37\%) tested MDR strains. However, the antibacterial activities of other extracts were also improved on few selected bacteria. These results suggest that these extracts (C. sinensis especially) have an intracellular targets.

Effects of Association of Extracts with Antibiotics. The reduced efficiency of known antibiotics propels many researchers to search for novel compounds, as well as molecules capable of improving or at least restoring the efficiency of available antibiotics against resistant bacteria. The combination of both compounds can then help to prevent the emergence of resistant mutants and enable restoring the activity of antibiotics vis-à-vis resistant strains. Synergies with FIC ranging from 0.5 to $<0.007$ were noted with the associations of each of the extracts and antibiotics on at least one tested MDR bacteria. The extracts from leaves of $M$. indica and $C$. sinensis and also that from peels of $C$. sinensis had important synergistic effects with most of the tested antibiotics against the majority of bacteria. These results suggest that extracts inhibited the efflux pumps, increasing the activity of these antibiotics [72, 73]. Few cases of indifference $(1 \leq$ FIC $<$ 4) were found in the majority of associations; meanwhile antagonistic effect was obtained when $C$. edulis extract was combined with streptomycin against E. aerogenes EA-CM64 strain. All plants tested in the present study (Table 1) are used traditionally to treat several affections or diseases with symptoms related to microbial infections $[8-10,16,17,19$, $20,27,29,40]$, and data obtained therefore consolidate their traditional use. The presence of previously reported secondary metabolites in the tested plants $[11,12,18,21,22,27$, $30,31,40,41$ ] (Table 1) is also in accordance with the present studies and could in part justify their antibacterial effects. Natural compounds belonging to terpenoids (for example, camosic acid and isopimarane derivatives), flavonoids (for example, $5^{\prime}$-methoxyhydnocarpin) as well as alkaloids (for example, pheophorbide $\mathrm{A}$ or reserpine) and others have been identified as efflux pumps inhibitors [74, 75]. Extract from $M$. indica and $C$. sinensis having the best synergistic effects contain all these classes of secondary metabolites, probably explaining their antibiotic potentiation effects. These results could be explained by the interaction between active compounds of extracts and the active ingredients of antibiotics.

\section{Limitations}

Our study has limitations. It mainly reports the activity of crude plant extracts and the identification of the active constituents of the plant would be necessary for better understanding of the reported effects. Though this study deals with food plants, the cytotoxicity studies in normal cell lines will be performed to ascertain their safety. 


\section{Conclusion}

The results of this study can provide some explanations on the traditional use of certain parts of the plants tested herein to combat infections, particularly those caused by enteric bacteria. Evidence of the antibacterial activity of the studied plants, especially edible ones, as well as the ability of some of them to improve the activity of commonly used antibiotics, is an indication that there is a possibility of discovering alternative antibacterials in these plants.

$\begin{array}{ll}\text { Abbreviations } \\ \text { AMP: Ampicillin } \\ \text { ATCC: American type culture collection } \\ \text { CEF: } & \text { Cefepime } \\ \text { CFU: } & \text { Colony forming unit } \\ \text { CHL: } & \text { Chloramphenicol } \\ \text { CIP: } & \text { Ciprofloxacin } \\ \text { DMSO: } & \text { Dimethylsulfoxide } \\ \text { EPI: } & \text { Efflux pump inhibitor } \\ \text { ERY: } & \text { Erythromycin } \\ \text { FIC: } & \text { Fractional inhibitory concentration } \\ \text { INT: } & \text { p-Iodonitrotetrazolium chloride } \\ \text { KAN: } & \text { Kanamycin } \\ \text { MDR: } & \text { Multidrug-resistant } \\ \text { MHB: } & \text { Mueller-Hinton Broth } \\ \text { MIC: } & \text { Minimal inhibitory concentration } \\ \text { PAßN: } & \text { Phenylalanine-arginine- } ß-n a p h t h y l a m i d e \\ \text { RND: } & \text { Resistance nodulation-cell division } \\ \text { STR: } & \text { Streptomycin } \\ \text { TET: } & \text { Tetracycline. }\end{array}$

\section{Conflicts of Interest}

The authors declare that they have no conflicts of interest.

\section{Authors' Contributions}

Joachim K. Dzotam carried out the study; Victor Kuete designed the experiments. Joachim K. Dzotam and Victor Kuete wrote the manuscript; Victor Kuete supervised the work and provided the bacterial strains; all authors read and approved the final manuscript.

\section{Acknowledgments}

The authors acknowledge the Cameroon National Herbarium for identification of plants.

\section{References}

[1] S. B. Levy and T. F. O’Brien, "Global antimicrobial resistance alerts and implications," Clinical Infectious Diseases, vol. 41, no. 4, pp. S219-S220, 2005.

[2] F. M. Aarestrup, "Veterinary drug usage and antimicrobial resistance in bacteria of animal origin," Basic and Clinical Pharmacology and Toxicology, vol. 96, no. 4, pp. 271-281, 2005.
[3] K. Bush and G. H. Miller, "Bacterial enzymatic resistance: $\beta$ lactamases and aminoglycoside-modifying enzymes," Current Opinion in Microbiology, vol. 1, no. 5, pp. 509-515, 1998.

[4] X. Z. Li and H. Nikaido, "Efflux-mediated drug resistance in bacteria: an update," Drugs, vol. 69, no. 12, pp. 1555-1623, 2009.

[5] A. Mahamoud, J. Chevalier, S. Alibert-Franco, W. V. Kern, and J.-M. Pagès, "Antibiotic efflux pumps in Gram-negative bacteria: The inhibitor response strategy," Journal of Antimicrobial Chemotherapy, vol. 59, no. 6, pp. 1223-1229, 2007.

[6] R. Verpoorte, "La Pharmacognosie du Nouveau Millénaire: Pistes et Biotechnologies. Des Sources du Savoir aux Médicaments du Futur," in Proceedings of the 4th European Congress of Ethnopharmacology, p. 274, IRD Edition, Paris, France, 2002.

[7] J. D. D. Tamokou, M. F. Tala, H. K. Wabo, J. R. Kuiate, and P. Tane, "Antimicrobial activities of methanol extract and compounds from stem bark of Vismia rubescens," Journal of Ethnopharmacology, vol. 124, no. 3, pp. 571-575, 2009.

[8] S. M. El Sohafy, A. M. Metwalli, F. M. Harraz, and A. A. Omar, "Quantification of flavonoids of Psidium guajava L. preparations by Planar Chromatography (HPTLC)," Pharmacognosy Magazine, vol. 4, no. 17, pp. 61-66, 2009.

[9] S.-C. Shen, F.-C. Cheng, and N.-J. Wu, "Effect of guava (Psidium guajava linn.) leaf soluble solids on Glucose metabolism in type 2 diabetic rats," Phytotherapy Research, vol. 22, no. 11, pp. 14581464, 2008.

[10] N. Nundkumar and J. A. O. Ojewole, "Studies on the antiplasmodial properties of some South African medicinal plants used as antimalarial remedies in zulu folk medicine," Methods and Findings in Experimental and Clinical Pharmacology, vol. 24, no. 7, pp. 397-401, 2002.

[11] A. A. T. Carvalho, M. C. C. Sampaio, A. F. M. Melo, F. C. Sampaio, K. X. F. R. Sena et al., "Atividade Antimicrobiana in Vitro de Extratos Hidroalcoólicos Psidium guajava L. Sobre Bactérias GramNegativas," Acta Farmacéutica Bonaerense, vol. 21, pp. 255-258, 2002.

[12] K. Nisha, M. Darshana, G. Madhu, and M. K. Bhupendra, "GC-MS analysis and anti-microbial activity of Psidium guajava (leaves) grown in Malva region of India," International Journal of Drug Development and Research, vol. 3, no. 4, pp. 237-245, 2011.

[13] W. C. Lee, R. Mahmud, S. Pillai, S. Perumal, and S. Ismail, "Antioxidant Activities of Essential Oil of Psidium Guajava L. Leaves," APCBEE Procedia, vol. 2, pp. 86-91, 2012.

[14] D. L. Valle Jr., J. I. Andrade, J. J. M. Puzon, E. C. Cabrera, and W. L. Rivera, "Antibacterial activities of ethanol extracts of Philippine medicinal plants against multidrug-resistant bacteria," Asian Pacific Journal of Tropical Biomedicine, vol. 5, no. 7, pp. 532-540, 2015.

[15] T. V. Braga, R. G. Dores, C. S. Ramos et al., "Antioxidant, Antibacterial and Antitumor Activity of Ethanolic Extract of the Psidium guajava Leaves," American Journal of Plant Sciences, vol. 5, no. 23, pp. 3492-3500, 2014.

[16] Q.-Y. Lu, J. R. Arteaga, Q. Zhang, S. Huerta, V. L. W. Go, and D. Heber, "Inhibition of prostate cancer cell growth by an avocado extract: role of lipid-soluble bioactive substances," The Journal of Nutritional Biochemistry, vol. 16, no. 1, pp. 23-30, 2005.

[17] O. O. Adeyemi, S. O. Okpo, and O. O. Ogunti, "Analgesic and anti-inflammatory effects of the aqueous extract of leaves of Persea americana Mill (Lauraceae)," Fitoterapia, vol. 73, no. 5, pp. 375-380, 2002. 
[18] O. B. Nathaniel, A. S. Selina, K. M. John, B. Mercy, A. A. Sylvester, and B. M. Michael, "Phytoconstituents, antimicrobial and antioxidant properties of the leaves of Persea americana Mill cultivated in Ghana," Journal of Medicinal Plants Research, vol. 9, no. 36, pp. 933-939, 2015.

[19] P. Milind and D. Chaturvede, "Orange: Range of benefits," International Research Journal of Pharmacology, vol. 3, pp. 5963, 2012.

[20] N. A. Adham, "Ethnobotanical evaluation of plants used in the traditional treatment of gastrointestinal disease in ErbilKurdistan region/Iraq," World Journal of Pharmaceutical Sciences, vol. 3, no. 9, pp. 1776-1781, 2015.

[21] K. Ghasemi, Y. Ghasemi, and M. A. Ebrahimzadeh, "Antioxidant activity, phenol and flavonoid contents of 13 citrus species peels and tissues," Pakistan Journal of Pharmaceutical Sciences, vol. 22, no. 3, pp. 277-281, 2009.

[22] F. Gülay Kirbaşlar, A. Tavman, B. Dülger, and G. Türker, "Antimicrobial activity of Turkish Citrus peel oils," Pakistan Journal of Botany, vol. 41, no. 6, pp. 3207-3212, 2009.

[23] A. O. Kabra, G. B. Bairagi, A. S. Mahamuni, and R. S. Wanare, "In vitro antimicrobial activity and phytochemical analysis of the peels of Citrus medica L," in Proceedings of the International Journal of Research in Pharmaceutical and Biomedical Sciences, vol. 3, pp. 34-37, 2012.

[24] H. M. Herath, M. D. Chamikara, D. R. Dissanayake et al., "A Comparative Assessment of the Antibacterial Activity in Fruit Juice of Sri Lankan Sweet Orange Cultivars vis a vis Sour Orange," Journal of Agricultural Sciences, vol. 11, no. 1, pp. 13-23, 2016.

[25] M. Saïdani, W. Dhifi, and B. Marzouk, "Lipid evaluation of some Tunisian Citrus seeds," Journal of Food Lipids, vol. 11, no. 3, pp. 242-250, 2004.

[26] J. Silalahi, "Anticancer and health protective properties of citrus fruit components," Asia Pacific Journal of Clinical Nutrition, vol. 11, no. 1, pp. 79-84, 2002.

[27] B. C. Adebayo-Tayo and K. K. Ajibesin, "Antimicrobial Activities of Coula edulis," Research Journal of Medicinal Plant, vol. 2, no. 2, pp. 86-91, 2008.

[28] D. Zofou, M. Tene, M. N. Ngemenya, P. Tane, and V. P. K. Titanji, "in Vitro antiplasmodial activity and cytotoxicity of extracts of selected medicinal plants used by traditional healers of western cameroon," Malaria Research and Treatment, p. 6, 2011.

[29] G. M. M. Parvez, "Pharmacological activities of Mango (Mangifera indica): A Review," Journal of Pharmacognosy and Phytochemistry, vol. 5, no. 3, p. 1, 2016.

[30] K. Mahattanatawee, J. A. Manthey, G. Luzio, S. T. Talcott, K. Goodner, and E. A. Baldwin, "Total antioxidant activity and fiber content of select Florida-grown tropical fruits," Journal of Agricultural and Food Chemistry, vol. 54, no. 19, pp. 7355-7363, 2006.

[31] G. L. Pardo Andreu, R. Delgado, J. A. Velho, C. Curti, and A. E. Vercesi, "Mangiferin, a natural occurring glucosyl xanthone, increases susceptibility of rat liver mitochondria to calciuminduced permeability transition," Archives of Biochemistry and Biophysics, vol. 439, no. 2, pp. 184-193, 2005.

[32] D. N. Muanza, K. L. Euler, L. Williams, and D. J. Newman, "Screening for antitumor and anti-HIV activities of nine medicinal plants from Zaire," International Journal of Pharmacognosy, vol. 33, no. 2, pp. 98-106, 1995.

[33] Z.-G. Peng, J. Luo, L.-H. Xia, Y. Chen, and S.-J. Song, "CML cell line K562 cell apoptosis induced by mangiferin," Zhongguo shi yan xue ye xue za zhi/Zhongguo bing li sheng li xue hui = Journal of experimental hematology/Chinese Association of Pathophysiology, vol. 12, no. 5, pp. 590-594, 2004.

[34] A. Bhowmik, L. A. Khan, M. Akhter, and B. Rokeya, "Studies on the antidiabetic effects of Mangifera indica stem-barks and leaves on nondiabetic, type 1 and type 2 diabetic model rats," Bangladesh Journal of Pharmacology, vol. 4, no. 2, pp. 110-114, 2009.

[35] G. Bidla, V. P. K. Titanji, B. Joko, G. El-Ghazali, A. Bolad, and K. Berzins, "Antiplasmodial activity of seven plants used in African folk medicine," Indian Journal of Pharmacology, vol. 36, no. 4, pp. 245-246, 2004.

[36] Z. Shabani and A. Sayadi, "The antimicrobial in vitro effects of different concentrations of some plant extracts including tamarisk, march, acetone and mango kernel," Journal of Applied Pharmaceutical Science, vol. 4, no. 5, pp. 75-79, 2014.

[37] V. Vega-Vega, B. A. Silva-Espinoza, M. R. Cruz-Valenzuela et al., "Antimicrobial and antioxidant properties of by product extracts of mango fruit," Journal of Applied Botany and Food Quality, vol. 86, no. 1, pp. 205-211, 2013.

[38] A. Sahrawat, S. Pal, and S. K. Shahi, "Antibacterial activity of Mangifera indica (mango) leaves against drug resistant bacterial strains," International Journal of Advanced Research, vol. 1, no. 6, pp. 82-86, 2013.

[39] L. Tona, K. Kambu, N. Ngimbi et al., "Antiamoebic and spasmolytic activities of extracts from some antidiarrhoeal traditional preparations used in Kinshasa, Congo," Phytomedicine, vol. 7, no. 1, pp. 31-38, 2000.

[40] A. B. Sharangi, "Medicinal and therapeutic potentialities of tea (Camellia sinensis L.) - a review," Food Research International, vol. 42, no. 5-6, pp. 529-535, 2009.

[41] P. M. Moderno, M. Carvalho, and B. M. Silva, "Recent patents on Camellia sinensis: source of health promoting compounds," Recent Patents on Food, Nutrition \& Agriculture, vol. 1, no. 3, pp. 182-192, 2009.

[42] E. W. C. Chan, Y. Y. Lim, and Y. L. Chew, "Antioxidant activity of Camellia sinensis leaves and tea from a lowland plantation in Malaysia," Food Chemistry, vol. 102, no. 4, pp. 1214-1222, 2007.

[43] J. B. Harbone, Phytochemical Methods: A Guide to Modern Techniques of Plant Analysis, Chapman and Hall Ltd., London, UK, 1973.

[44] H. M. P. Poumale, R. Hamm, Y. Zang, Y. Shiono, and V. Kuete, "Coumarins and Related Compounds from the Medicinal Plants of Africa," Medicinal Plant Research in Africa: Pharmacology and Chemistry, pp. 261-300, 2013.

[45] J. A. Seukep, A. G. Fankam, D. E. Djeussi et al., "Antibacterial activities of the methanol extracts of seven Cameroonian dietary plants against bacteria expressing MDR phenotypes," SpringerPlus, vol. 2, no. 1, pp. 1-8, 2013.

[46] F. K. Touani, A. J. Seukep, D. E. Djeussi, A. G. Fankam, J. A. K. Noumedem, and V. Kuete, "Antibiotic-potentiation activities of four Cameroonian dietary plants against multidrug-resistant Gram-negative bacteria expressing efflux pumps," BMC Complementary and Alternative Medicine, vol. 14, article no. 258, 2014.

[47] J. N. Eloff, "A sensitive and quick microplate method to determine the minimal inhibitory concentration of plant extracts for bacteria," Planta Medica, vol. 64, no. 8, pp. 711-713, 1998.

[48] V. Kuete, A. T. Mbaveng, M. Tsaffack et al., "Antitumor, antioxidant and antimicrobial activities of Bersama engleriana (Melianthaceae)," Journal of Ethnopharmacology, vol. 115, no. 3, pp. 494-501, 2007. 
[49] V. Kuete, G. F. Wabo, B. Ngameni et al., "Antimicrobial activity of the methanolic extract, fractions and compounds from the stem bark of Irvingia gabonensis (Ixonanthaceae)," Journal of Ethnopharmacology, vol. 114, no. 1, pp. 54-60, 2007.

[50] V. Kuete, F. Nana, B. Ngameni, A. T. Mbaveng, F. Keumedjio, and B. T. Ngadjui, "Antimicrobial activity of the crude extract, fractions and compounds from stem bark of Ficus ovata (Moraceae)," Journal of Ethnopharmacology, vol. 124, no. 3, pp. 556-561, 2009.

[51] A. G. Fankam, V. Kuete, I. K. Voukeng, J. R. Kuiate, and J.-M. Pages, "Antibacterial activities of selected Cameroonian spices and their synergistic effects with antibiotics against multidrugresistant phenotypes," BMC Complementary and Alternative Medicine, vol. 11, p. 104, 2011.

[52] I. K. Voukeng, V. Kuete, J. P. Dzoyem et al., "Antibacterial and antibiotic-potentiation activities of the methanol extract of some cameroonian spices against Gram-negative multi-drug resistant phenotypes," BMC Research Notes, vol. 5, p. 299, 2012.

[53] L. C. Braga, A. A. M. Leite, K. G. S. Xavier et al., "Synergic interaction between pomegranate extract and antibiotics against Staphylococcus aureus," Canadian Journal of Microbiology, vol. 51, no. 7, pp. 541-547, 2005.

[54] H. D. M. Coutinho, A. Vasconcellos, H. L. Freire-Pessôa, C. A. Gadelha, T. S. Gadelha, and G. G. Almeida-Filho, "Natural products from the termite Nasutitermes corniger lowers aminoglycoside minimum inhibitory concentrations," Pharmacognosy Magazine, vol. 6, no. 21, pp. 1-4, 2010.

[55] M. M. Cowan, "Plant products as antimicrobial agents," Clinical Microbiology Reviews, vol. 12, no. 4, pp. 564-582, 1999.

[56] V. Kuete, J. Kamga, L. P. Sandjo et al., "Antimicrobial activities of the methanol extract, fractions and compounds from Ficus polita Vahl. (Moraceae)," BMC Complementary and Alternative Medicine, vol. 11, article 6, 2011.

[57] V. Kuete, B. Wiench, M. S. Alsaid et al., "Cytotoxicity, mode of action and antibacterial activities of selected Saudi Arabian medicinal plants," BMC Complementary and Alternative Medicine, vol. 13, p. 354, 2013.

[58] S. B. Tankeo, P. Tane, and V. Kuete, "In vitro antibacterial and antibiotic-potentiation activities of the methanol extracts from Beilschmiedia acuta, Clausena anisata, Newbouldia laevis and Polyscias fulva against multidrug-resistant Gram-negative bacteria," BMC Complementary and Alternative Medicine, vol. 15, p. 412, 2015.

[59] J. K. Dzotam, F. K. Touani, and V. Kuete, "Antibacterial and antibiotic-modifying activities of three food plants (Xanthosoma mafaffa Lam., Moringa oleifera (L.) Schott and Passiflora edulis Sims) against multidrug-resistant (MDR) Gram-negative bacteria," BMC Complementary and Alternative Medicine, vol. 16, no. 1, pp. 1-8, 2016.

[60] A. R. Ndhlala, S. O. Amoo, B. Ncube, M. Moyo, J. J. Nair et al., "16 - Antibacterial, Antifungal, and Antiviral Activities of African Medicinal Plants," in Kuete V, Medicinal Plant Research in Africa, Ed., pp. 621-659, Elsevier, Oxford, UK, 2013.

[61] O. E. Charles, A. A. Anthony, S. M. Kwaliafon, N. I. Nneka, and F. C. Kennedy, "Antimicrobial activity of Psidium guajava Linn. stem extracts against methicillin-resistant Staphylococcus aureus," African Journal of Biotechnology, vol. 11, no. 89, pp. 15556-15559, 2012.

[62] V. Kuete and T. Efferth, "Cameroonian medicinal plants: Pharmacology and derived natural products," Frontiers in Pharmacology, vol. 1, p. 123, 2010.
[63] I. Stoilova, S. Gargova, A. Stoyanova, and L. Ho, "Antimicrobial and antioxidant activity of the polyphenol mangiferin," Herb Polonica, vol. 51, pp. 37-44, 2005.

[64] C. Engels, A. Schieber, and M. G. Gänzle, "Inhibitory spectra and modes of antimicrobial action of gallotannins from mango kernels (Mangifera indica L.)," Applied and Environmental Microbiology, vol. 77, no. 7, pp. 2215-2223, 2011.

[65] S. Archana and J. Abraham, "Comparative analysis of antimicrobial activity of leaf extract from fresh green tea, commercial green tea and black tea on pathogens," Journal of Applied Pharmaceutical Science, vol. 1, no. 8, pp. 149-152, 2011.

[66] P. Anita, I. Balan, S. Ethiraj, P. Madan Kumar, and S. Sivasamy, "In vitro antibacterial activity of Camellia sinensis extract against cariogenic microorganisms," Journal of Basic and Clinical Pharmacy, vol. 6, no. 1, pp. 35-39, 2015.

[67] H. Tsuchiya, "Effects of green tea catechins on membrane fluidity," Pharmacology, vol. 59, no. 1, pp. 34-44, 2006.

[68] S. M. Saleh, B. H. Saleh, and A. E. S. Bahjat, "Antimicrobial Activity of Water and Methanol Leaf Extracts of Green Tea (Camellia Sinensis) Against Some Pathogenic Bacteria," Journal of Al-Nahrain University, vol. 17, pp. 162-167, 2014.

[69] J. D. D. Tamokou, A. T. Mbaveng, and V. Kuete, "Chapter 8 - Antimicrobial Activities of African Medicinal Spices and Vegetables," in Medicinal Spices and Vegetables from Africa, pp. 207-237, Kuete V: Academic Press, London, UK, 2017.

[70] J. A. Bohnert and W. V. Kern, "Selected arylpiperazines are capable of reversing multidrug resistance in Escherichia coli overexpressing RND efflux pumps," Antimicrobial Agents and Chemotherapy, vol. 49, no. 2, pp. 849-852, 2005.

[71] N. Mesaros, F. Van Bambeke, Y. Glupczynski, R. Vanhoof, and P. M. Tulkens, "Lefflux des antibiotiques: un mécanisme ubiquitaire conduisant à la résistance. Etat de la question et implications microbiologiques et cliniques," Louvain Medical, vol. 124, no. 8, pp. 308-320, 2005.

[72] V. Lorenzi, A. Muselli, A. F. Bernardini et al., "Geraniol restores antibiotic activities against multidrug-resistant isolates from gram-negative species," Antimicrobial Agents and Chemotherapy, vol. 53, no. 5, pp. 2209-2211, 2009.

[73] B. Zechini and I. Versace, "Inhibitors of multidrug resistant efflux systems in bacteria," Recent Patents on Anti-Infective Drug Discovery, vol. 4, no. 1, pp. 37-50, 2009.

[74] B. Marquez, "Bacterial efflux systems and efflux pumps inhibitors," Biochimie, vol. 87, no. 12, pp. 1137-1147, 2005.

[75] M. Ahmed, C. M. Borsch, A. A. Neyfakh, and S. Schuldiner, "Mutants of the Bacillus subtilis multidrug transporter Bmr with altered sensitivity to the antihypertensive alkaloid reserpine," Journal of Biological Chemistry, vol. 268, no. 15, pp. 1108611089, 1993. 

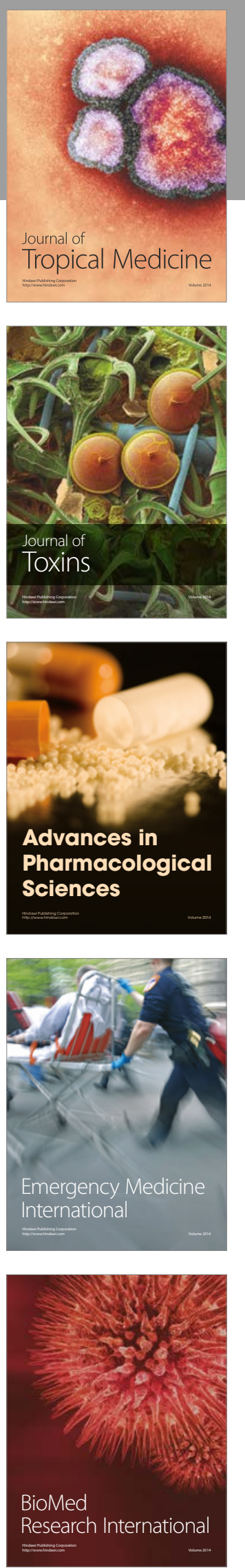
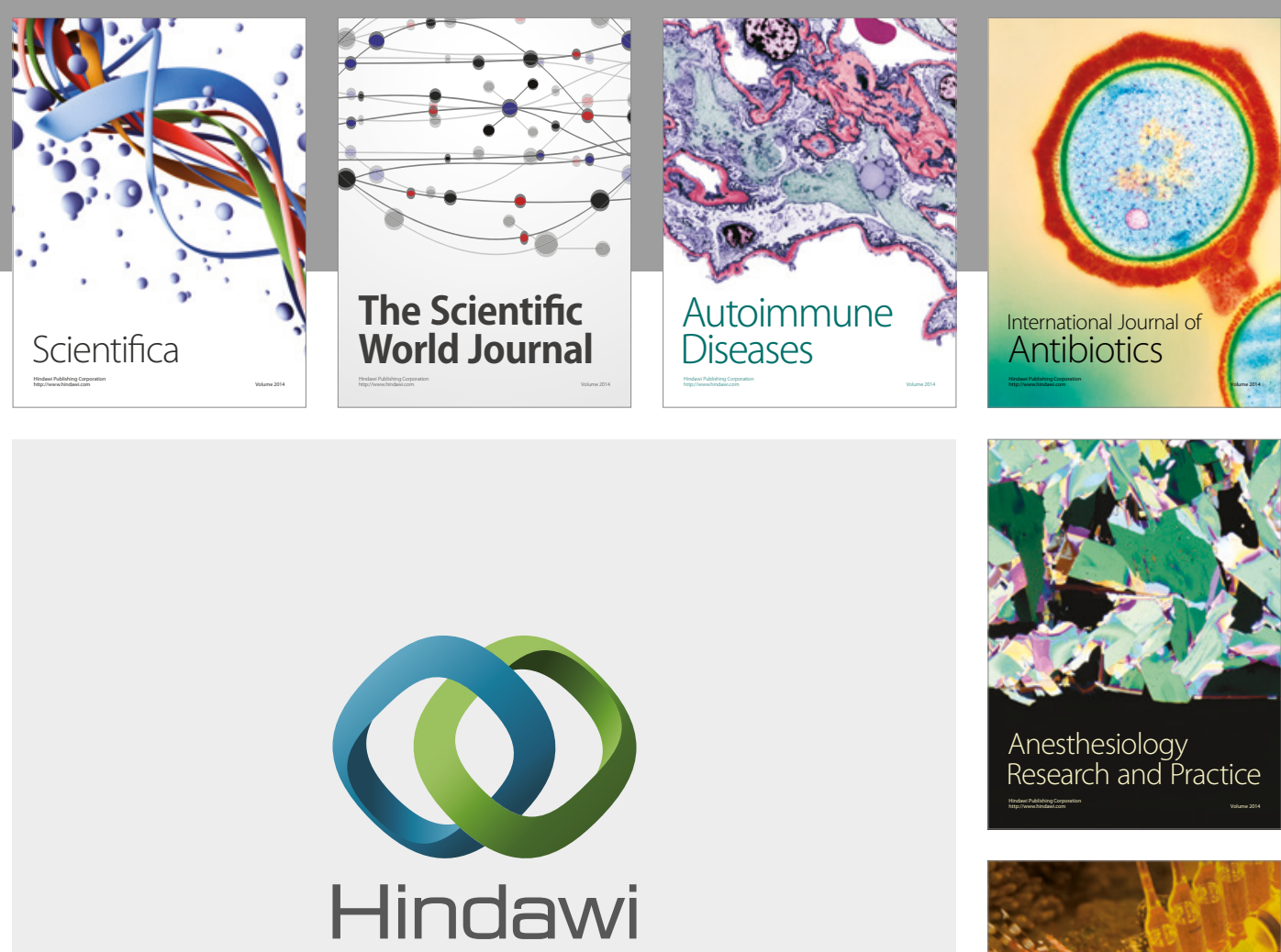

Submit your manuscripts at

https://www.hindawi.com
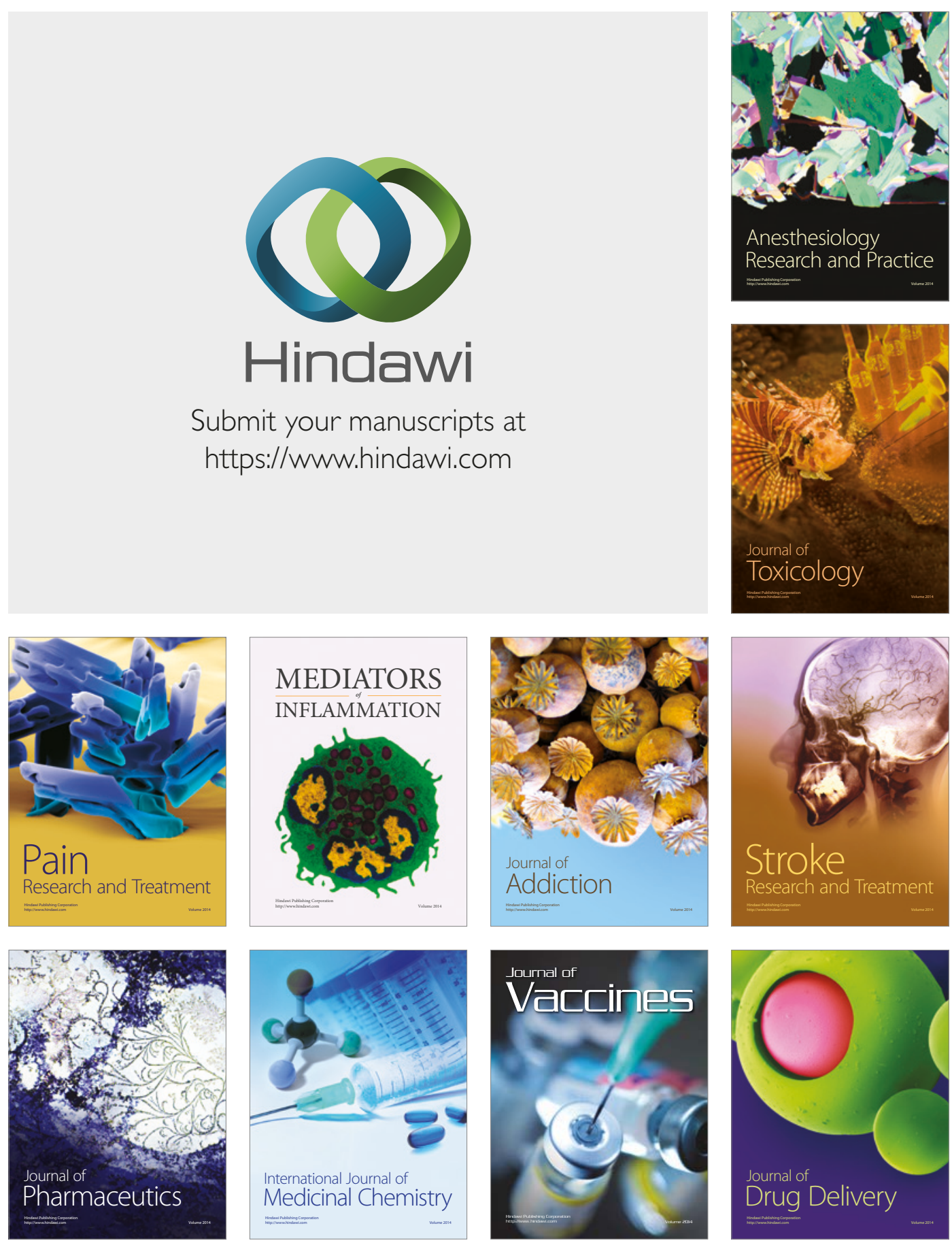